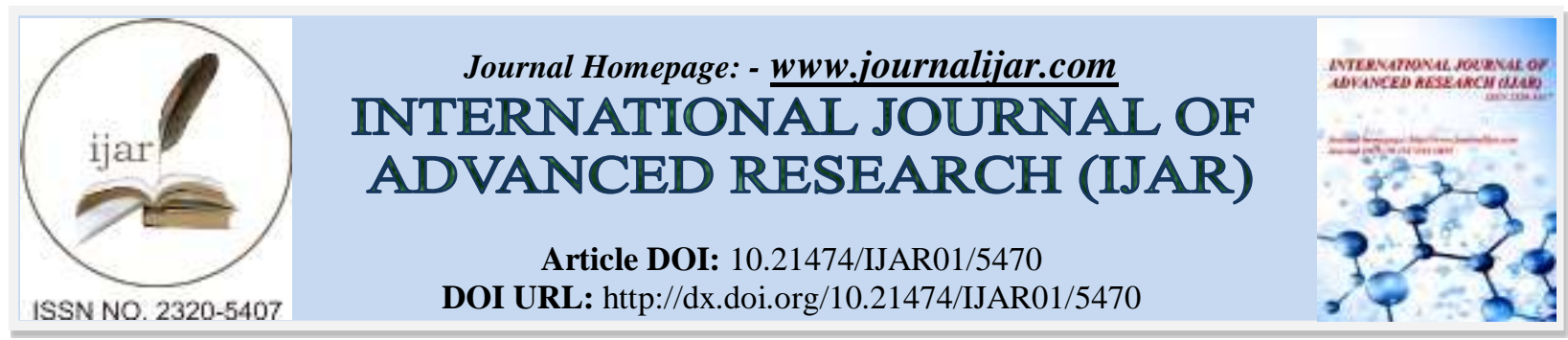

RESEARCH ARTICLE

\title{
FAST FOOD CONSUMPTION AND ITS ASSOCIATION WITH OBESITY AMONG FEMALE COLLEGE STUDENTS IN AL-MEDINA AL-MUNWARAH, SAUDI ARABIA: A CROSS SECTIONAL STUDY.
}

\author{
Nermin Nagah Elnashar and Suha Hashim Abduljawad. \\ Nutrition and food science Department, College of Family science, Taibah University, Al-Medina Al-Munwarah, \\ Saudi Arabia.
}

\section{Manuscript Info}

Manuscript History

Received: 19 July 2017

Final Accepted: 21 August 2017

Published: September 2017

\section{Key words:-}

Al-Medina Al-Munwarah, Fast food, obesity, college female students, body mass index

\begin{abstract}
Nowadays, Fast food consumption seem to be usual among adolescents in Saudi Arabia. Such a situation is an alarming increase in the prevalence of chronic non-communicable diseases (NCD) such as diabetes, heart diseases and cancer which are estimated to account for $78 \%$ of all deaths. This study was done to assess the awareness of health hazards, consumption pattern of fast foods and to find out its association with obesity among college students. This cross-sectional study was done among 100 students enrolled in the division of home economics and technical education at the Educational College preparatory of female teachers in Al-Medina Al-Munwarah during the second term from (1429-1430). Subjects were 19 years and up, and completed an initial questionnaire to determine the prevalence of consumption of fast food. All of the female student participants in this study answered the questions in specific questionnaire to allow us to understand better their dietary habits. Results indicates that the presence of the highest increase weight ratio according to the body mass index (B.M.I) which was found in student girls as (37.9\%), which the ratio of what described as obesity state (B.M.I $=30$ or above) the highest in student is (17.02\%). It was observed that $1.41 \%$ were likely to be diabetic (with blood glucose levels $6.08-7.2 \mathrm{mmol} / \mathrm{l}$ ) whom consumed fast food more than three times a week, $98.8 \%$ in the uncertain group (blood glucose were normal levels 4.6-6.9 mmol/l). Students consuming fast food two times or less had normal levels of plasma cholesterol as well triglyceride. This resulted in no change in the cholesterol and triglyceride, the plasma lipid response to consumption of fast food three times or more was also as expected. Cholesterol levels were increased in only $1.34 \%$ of group 2 , and triglycerides levels were increased by fast food consumption in $1.12 \%$ of group 2. In conclusion, our investigation suggests that fast food consumption among students affects diet quality in ways that would plausibly increase risk for obesity, regardless of baseline body weight. public health measures to limit fast food consumption in students may be warranted. Such measures could include nutrition education campaigns, legislation to regulate marketing of fast food to students, and elimination of fast food from Colleges.
\end{abstract}

Corresponding Author:- Nermin Nagah Elnashar.

Address:- Nutrition and food science Department, College of Family science, Taibah University, AlMedina Al-Munwarah, Saudi Arabia. 


\section{Introduction:-}

Fast food, by definition, is "designed for ready availability, use, or consumption with little consideration given to quality or significance" (Merriam-Webster's, 2015). The energy density of these food stuffs had been found to be more than twice the recommended daily allowance for adults (Printice and Jebb, 2003). Experts therefore attribute the current obesity epidemic to fast foods (Ashakiran, 2012).

These food stuffs generally consist of food such as hamburgers, French fries, chicken nuggets, pizza and shawarma. Fast food is highly processed and prepared using standardized ingredients and production techniques, usually rich food additives. Much fast food is energy-dense meals often due to a high content of fat and refined starches and sugars and a correspondingly low water content. Due to deep-frying in partially hydrogenated oils (or trans fats), fast food consumption leads to high cholesterol rates and heart attacks (Schlosser, 2012). Combined with starchy vegetables and sugary drinks, these foods have a high glycemic load, a factor that contributes to obesity and diabetes (Ludwig and Robert, 2002). On the other hand, several studies have been suggested that fast food was associated with low intake of vegetables, fruits and milk in both adult and children which might lead to some micronutrient deficiencies (Paeratakul et al., 2003). Unfortunately, food additives which used in these food stuffs are found to be carcinogenic and can be allergic causing asthma and rashes (Ashakiran, 2012).

The prevalence of obesity, especially among females, in Saudi Arabia has increased dramatically during the past decades (Musaiger, 2000). This increase in the prevalence of obesity is due to nutrition transition which are in relation with changing economic, social, and health factors. Major dietary changes include a large increase in an unbalanced diet rich in carbohydrates and fat and poor in dietary fiber consumption because of increased food intake outside the home, mostly fast foods (Al-Hazzaa et al., 2013).

College students are highly exposed to unhealthy eating habits and obesity. In KSA, Khamis et al. (2014) documented that the fast food consumption was $100 \%$ among male and female students University in Jeddah (West region), with $81.3 \%$ and $13.1 \%$ on a weekly and daily basis, respectively. A study carried out in another city in the West region (Al Qassim city) indicated that about third of male student university consumes fried food 3-4 times per week and one another third consumed it 1-2 times per week (Al-Rethaiaa et al., 2010). In Dammam (East region), this percentage was within more or less the range reflecting the very high fast food intake among the university students community. It was reported that $64.2 \%$ of male students university consumed fast foods 1-5 per weeks and one the fifth consumed fast food in a frequency of 6-10 times per week (Sabra et al., 2007). Females students University seem to behave on the same basis. Alfawaz (2012) has shown that $22.7 \%$ of university female students in Riyadh (Centre) were consuming fast food 3-4 times per week and 74.5\% 1-2 times per week.

Benajiba (2016) explained that fast foods were the major dietary changes reported for university students. In addition, she clarified that the lack of experience in planning meals and assuming responsibility for food purchasing are the main factors underlying this excessive unhealthier dietary behavior among University students.

Therefore, this study was done to find out the awareness of health hazards of fast foods, consumption pattern of fast foods and its association with obesity among female college students in Al-Medina Al-Munwarah.

\section{Subjects and Methods:-}

The study group included a random sample of 100 students enrolled in the division of home economics and technical education at the Educational College preparatory of female teachers in Al-Medina Al-Munwarah during the second term from (1429-1430). Subjects were 19 years and up, and completed an initial questionnaire to determine the prevalence of consumption of fast food.

Research data will be collected from students using a structured questionnaire that includes information on sociodemographic factors. All of the female student participants in this study answered the questions in specific questionnaire to allow us to understand better their dietary habits. The questions included information about dietary awareness, the student ignorance level and the consequences of missing one dietary meal. In addition to understanding the exchange of important meals by snack foods, the timing and foods provided for the dinner meal, if 
it is light or fatty solid. Whether or not if the student buys or eats the fast food that was prepared at a restaurant, depends more about the individual preferences and for example dieting by eating potato chips and other light meals. Overall, the questionnaire included 18 multiple-choice questions and two open-ended questions. The survey is designed to take no more than 10 minutes to complete. Survey questions focused on the following two topics regarding fast food and the respondent's eating habits:

1. Frequency of consuming fast food items

2. Places and time of eating

Anthropometrics measurement:-

Weight was measured without shoes to the nearest $0.1 \mathrm{~kg}$ using a Seca personal scale (model 777, West Germany). Height was taken barefooted to the nearest $0.1 \mathrm{~cm}$ using a standard measuring tape. Body mass index (BMI) was calculated as the weight $/$ height $(\mathrm{kg} / \mathrm{m} 2)$. Overweight was defined as BMI of 85 th percentile to $<95$ th percentile among age specific strata, while obesity was defined as BMI of $95^{\text {th }}$ percentile among age specific strata (Must, et al., 1999) which concerns the body mass index as follows:

\begin{tabular}{|l|l|}
\hline The Body Mass State & The Body Mass index (B.M.I) \\
\hline The thinness a thinner male or female. & Less than 20 \\
\hline The healthy weight. & From $20-24.9$ \\
\hline Overweight male or a female & From $25-29.9$ \\
\hline The obesity obese male or a female. & 30 and above \\
\hline
\end{tabular}

\section{Biochemistry measurement:-}

Each student was requested to come on a mutually agreed day following 12 hours of fasting prior to blood collection. 3-5 $\mathrm{ml}$ of blood was drawn by a venipuncture method. Glucose was measured immediately using a glucometer (One Touch II). The rest of the blood was centrifuged at 3000 RPM's for 5 minutes to separate the plasma from the cells. The cellular layer was discarded and the plasma was stored frozen at $-20^{\circ} \mathrm{C}$ until it is required for further analysis.

\section{Statistical Analysis:-}

Questionnaires were checked and coded, and data was analyzed using the Epi - info program. Also, the Chi square and Statistical Package for Social Sciences (SPSS Inc., Chicago, IL, USA) version 17 was used for data analysis. Results were expressed as means \pm standard deviations. All of the analyzed variables were non-parametric and were tested using Chi-squared tests. All reported $\mathrm{P}$ values were made based on two-tailed tests. Differences were considered statistically significant at $\mathrm{P}$ value $<0.05$.

\section{Results and Discussion:-}

\section{Effect of fast food consumption on obesity:-}

The data in table no. 1 indicates the presence of the highest increase weight ratio according to the body mass index (B.M.I) which was found in student girls as $(37.9 \%)$, which the ratio of what described as obesity state (B.M.I $=30$ or above) the highest in student is (17.02\%), then the ratio of the students that have an increase weight above the natural limits and included overweight ones is $(37.9 \%)$ while the ratio of students that have decreased weigh less than the accurate limit according to the body mass index of less than 20 is $7.02 \%$, and the thinner ones require special diet care by acquiring correct dietary customs to improve their bodies weights. These findings were consistent with the results of similar studies in other Middle East and some Western countries. In Lebanon, the prevalence of overweight and obesity among male college students was 37.5\% and $12.5 \%$, respectively (Yahia, et al.,2008). In United States and the United Arab Emirates overweight and obese accounted for about 35\% of the male college students (Musaiger, et al., 2003).

Table no. (2) shows that the high ratio of the female students reached about (35.09\%). They don't always take care of one main meal intake and instead of it, they take the snack meal as a substitute, in addition to that there are students who are very rarely miss a meal with a ratio of $(56.14 \%)$ but the rest of girl students who regularly take their three main daily meals with a less ratio about $(8.77 \%)$.

The markets of fast food meals such as hamburgers, potato chips and soft drinks became widespread. Table no. (3) refers to female students' intake of light meal as potato chips between their main meals and this was eaten by the students majority about (52.63\%), and the students who took it from time to time about (35.96\%). This means that 
the students who always or sometimes take light meals about $(88.59 \%)$ as well as there were differences with statically inference of confidence interval less than $(0.01 \%)$ of female students with their buying of snack food. Musaiger et al., (2003) were published by the Ministry of Health about the dietary habits in the United Arab Emirates referred to (15\%) of the families who offered light meals to its members between the main meals.

Table no. (4) shows fast food meals diversification which female students tend to take. Also, there were multi fast food meals with the upper and higher intake by the student specifically MacDonald's beef and chicken meals because it was cheap compared with others and followed by Pizza Hut meals that are rich with cheese and vegetables. As such, students reduced their buying of Hardies' because it was expensive and there were not any group that preferred domains pizza. We also noted differences (variations) with statically inference and confidence interval less than (0.01) which concerned the students' tendency to buy only some kinds of fast food items with the exclusion of others.

There were also some variations with statically inference between the body mass index of the obese and overweight female students and their increase intake of fast food meals; it appeared that there is a correlation between consuming fast food and obesity that was reported in studies (Francis et al., 2003; Alviola et al.,2014). Also, there were not any statically discrepancies whether they were thinner or with healthy bodies who take the light meals as explained in the table no. (5).

Table no. (6) shows that about (42.00\%) of the students consume fast food meal two times a week and the rest of the students three times or more a week as about $(32.70 \%)$ consumed fast food three times every week. The high increase of female students consuming fast food was attributed to their long presence out of their homes during their school hours as they prefer to consume fast food during supper over the weekend. The discrepancies were abstract among the female students in buying fast food which had statistical inference and confidence interval less than (0.01). Musaiger and Radwan (1995) demonstrated that about (70\%) of the families there bought the fast foods from the restaurants.

It was noted that according to the relationship of their body mass and their frequent intake of the fast food as mentioned in the table no. (4), there was abstract discrepancies with statistical inference. Also, there was variation in studying according to their bodies mass index and their intake of fast food where the number of times intake (Musaiger, 1994; Musaiger \& Radwan, 1995; Rashad et al., 2006) connected with the body mass increase and the obesity. There weren't any discrepancies with the students statistical inference who have the accurate healthy weight or the thinner ones as in table no. (7).

People are different in the nature of their supper contents; some take light meals as the green salad and fruits with its juices and the other take fatty dishes as fried beef with oil or the sandwiches that are filled with greasy cheese or tuna (tunny fish) with mayonnaise. Table no. (8) refers to small ratio of the female student about (7.020\%) who always take light food in their supper. Also, there is a high percentage that includes all participants in the study who were taken sometimes light food and other time greasy one and their percentage about (84.215\%). It was noted that there were abstract discrepancies with statistical inference less than (0.05) among the students preference in taking light food in the dinner meal.

\section{Effect of Fast food consumption on blood glucose:-}

Random blood sugar levels were recorded for 100 students in this study and placed into the categories in relation to fast food consumption based on random sugar assessment (WHO, 2016). The statistical data of glucose in the studied females is presented in Table 9.

In group 1, the minimum blood glucose value was $3.7 \mathrm{mmol} / \mathrm{l}$ and the maximum was $6.2 \mathrm{mmol} / \mathrm{l}$, with a mean of $4.61 \mathrm{mmol} / \mathrm{l}$, median of $4.4 \mathrm{mmol} / \mathrm{l}$ and mode of 4.2 . Comparison of the results from students who consumed fast food three time or more showed no significant difference in the mean of total glucose in the group 1 , by both students t test and Mann-Whitney test, where the glucose level was significantly higher in $1.41 \%$ from group2. In these group students, the mean, median, and mode of blood glucose were 6.08-7.00 mmol/1, $4.9 \mathrm{mmol} / 1$, and 4.9 $\mathrm{mmol} / \mathrm{l}$ respectively. The minimum value observed was $6.0 \mathrm{mmol} / \mathrm{l}$ and the maximum was $7.2 \mathrm{mmol} / \mathrm{l}$.

In group 2, the values of mean, median, and mode of blood glucose were $4.73 \mathrm{mmol} / \mathrm{l}, 4.6 \mathrm{mmol} / \mathrm{l}$, and $4.3 \mathrm{mmol} / \mathrm{l}$ respectively. The minimum value observed was $3.8 \mathrm{mmol} / \mathrm{l}$ and the maximum was $6.8 \mathrm{mmol} / \mathrm{l}$. As shown in table 
no. (9), it was observed that $1.41 \%$ were likely to be diabetic (with blood glucose levels $6.08-7.2 \mathrm{mmol} / \mathrm{l}$ ) whom consumed fast food more than three times a week, $98.8 \%$ in the uncertain group (blood glucose were normal levels 4.6-6.9 mmol/l). The responses to fast food seen in the students consuming the fast food diets which had highCaloric diet are similar in direction and magnitude to those differences reported based studies (Sandra et al., 2010; Phillips et al., 2004; Schmidt et al., 2005). The distribution of the mean and median blood glucose levels recorded is shown in table no. (9). Analysis indicated that the variation observed between the students was statistically significant refer consumption of fast food (t-test $<0.0001)$.

\section{Effect of Fast food consumption on blood cholesterol and triglycerides:-}

Food intake and the pattern of fast food consumption are lifestyle choices that modulate risk factors for CVD (Hegsted et al., 1993; Monheit et al., 2007; Anderson et al., 2011). Diets high in fat, particularly saturated fat, increase the incidence of CVD. The impact on CVD of fast food consumption which has a higher amount of dietary fat, in large part, were related to their effects on blood lipid and lipoprotein profiles. Individuals consuming a diet lower in fat were shown repeatedly to have lower plasma cholesterol and LDL cholesterol concentrations (Clevidence et al., 1995). Responses of other lipoproteins to changes in dietary fat levels were not as dramatic, see table no. (10).

From the Report of the National Cholesterol Education Program Expert Panel on Detection, Evaluation and Treatment of High Blood Cholesterol in adults. Arch Inter Med 1988; 148: 36. Distribution of total blood cholesterol and triglycerides levels of the study is given in tables (11-12). Three cholesterol levels were designated: normal, borderline and high (Roefs and Jansen, 2002).

The levels of cholesterol in the students are presented in table no. 11. The mean value of cholesterol in group 1 females was $4.84 \mathrm{mmol} / \mathrm{l}$. As this value was close to the median value $(4.81 \mathrm{mmol} / \mathrm{l})$ and mode value $(4.46 \mathrm{mmol} / \mathrm{l})$, this indicated a normal distribution for cholesterol in the studied females $97.5^{\text {th }}$ percentile range was 3.02-6.09 $\mathrm{mmol} / \mathrm{l}$ and the mean $\pm 2 \mathrm{SD}$ range was $2.49-6.78 \mathrm{mmol} / \mathrm{l}$. When the results in the two groups were analyzed separately, no significant difference was observed between the groups. The significant were $1.34 \%$ of group 2 . The mean, median, and mode of cholesterol in these group were $4.97 \pm 1.28$ which is normal and borderline high risk $\mathrm{mmol} / \mathrm{l}, 5.12 \mathrm{mmol} / \mathrm{l}$, and $4.58 \mathrm{mmol} / \mathrm{l}$, respectively, compared to the mean, median, and mode of cholesterol in group 2 students who consumed more three times a week of $4.87 \mathrm{mmol} / \mathrm{l}, 4.83 \mathrm{mmol} / \mathrm{l}$, and $4.58 \mathrm{mmol} / \mathrm{l}$, respectively.

Triglycerides were studied in a study and the results are presented in table no. (12). The mean, median, mode, SEM, $\mathrm{SD}$, and percentile ranges for triglycerides in two groups are listed. In $1.12 \%$ of group 2 , the values for mean, median and mode were $1.49 \pm 1.34 \mathrm{mmol} / \mathrm{l}, 1.34 \mathrm{mmol} / \mathrm{l}$, and $1.03 \mathrm{mmol} / \mathrm{l}$. As the values were not similar to each other this indicated a skewed distribution and that meant there was a significant difference between 1.34 percentage of group 2 and the others groups. When the results for two group's females were separately analyzed, no difference was seen in the triglycerides level in the two groups.

In the group that consumed two times in comparison with the group whom consumed three times or more the triglycerides mean was $1.10 \mathrm{mmol} / \mathrm{l}$ compared to $1.14 \mathrm{mmol} / \mathrm{l}$ in the $1.12 \%$. Within group 2 students, there was a difference between the two groups that was statistically significant. Within group 1 students, the minimum triglycerides value was $0.37 \mathrm{mmol} / \mathrm{l}$ and the maximum was $2.47 \mathrm{mmol} / \mathrm{l}$ with mean of $1.10 \mathrm{mmol} / 1$, median of 0.97 $\mathrm{mmol} / \mathrm{l}$, and mode of $0.61 \mathrm{mmol} / \mathrm{l}$. The percentile range was $0.39-2.34 \mathrm{mmol} / \mathrm{l}$ and the mean $\pm 2 \mathrm{SD}$ was $1.03 \pm 0.86$ $\mathrm{mmol} / \mathrm{l}$, while in group 2 females the values of mean, median, and mode of triglycerides were $1.14 \mathrm{mmol} / \mathrm{l}, 1.05$ $\mathrm{mmol} / \mathrm{l}, 0.61 \mathrm{mmol} / \mathrm{l}$, respectively. The mean $\pm 2 \mathrm{SD}$ range was $1.49 \pm 1.04 \mathrm{mmol} / \mathrm{l}$ and the percentile range was 0.82 $2.64 \mathrm{mmol} / \mathrm{l}$.

The effects of the fast food consumption on plasma lipids were as expected. Students consuming fast food two times or less had normal levels of plasma cholesterol as well triglyceride. This resulted in no change in the cholesterol and triglyceride, the plasma lipid response to consumption of fast food three times or more was also as expected. Cholesterol levels were increased in only $1.34 \%$ of group 2, and triglycerides levels were increased by fast food consumption in $1.12 \%$ of group 2 are similar in direction and magnitude to those differences reported in Tsung (2009), STAMPFER et al.(1997) and Currie et al.(2010). 
Such changes had been reported from a number of studies (Clevidence et al., 1995; Gold and Imbens, 2013; Maggio and Pi-Sunyer, 2003; Blume et al.,2013; Cheristakis and Flower, 2013; Alfawaz, 2012). where higher levels of fat in diets were administered. In this study, the increase in cholesterol and triglyceride accounted for the increase in blood profile. It was observed that $1.34 \%$ of group 2 had borderline high risk cholesterol levels (i.e. 5.18 - 6.19) who consumed fast food more than three times in a week and $9.7 \%$ were normal cholesterol levels. It was also observed that $1.12 \%$ of students had borderline high risk triglyceride levels compared to other students. For the analysis of the normal group of cholesterol levels it was found that the $89.7 \%$ percent of students was distributed among these levels who consumed fast food two times a week.

In conclusion, our investigation suggests that fast food consumption among students affects diet quality in ways that would plausibly increase risk for obesity, regardless of baseline body weight. public health measures to limit fast food consumption in students may be warranted. Such measures could include nutrition education campaigns, legislation to regulate marketing of fast food to students, and elimination of fast food from Colleges.

Table No. (1):- The student distribution according to body mass index

\begin{tabular}{|l|l|l|l|l|l|l|l|l|}
\hline & \multicolumn{2}{|l|}{ The } & \multicolumn{3}{c|}{ From 20 -24.9 } & \multicolumn{2}{l|}{ From 25-29.9 } & \multicolumn{2}{l|}{ 30 and above } \\
\hline Category & No. & \% & No. & \% & No & \% & No. & \% \\
\hline The & & 7,02 & & 37.9 & & 37.9 & & 17.02 \\
\hline Students & 8 & & 40 & & 40 & & 12 & \\
\hline Chi Square = 1.03 Confidence Interval, (CI) $=0,7945$. & & & & \\
\hline
\end{tabular}

Table No. (2):- The participants of the study negligence to one of their main meal and instead of it, they ate fast food as a substitute.

\begin{tabular}{|l|l|l|l|l|l|l|l|}
\hline The & Always neglect & \multicolumn{2}{l|}{ Rarely neglect } & \multicolumn{2}{l|}{ Absolute don't neglect } & The \\
\hline Category & No. & $\%$ & No. & \% & No. & \% & Total \\
\hline The & 35 & & 55 & & 10 & & 100 \\
\hline Students & \multicolumn{7}{|l|}{ CI $=0.0098$} \\
\hline Chi SQUARE $=9.23$ & 56.14 & & 8.77 \\
\hline
\end{tabular}

Table No. (3):- Students intake of the light meals between their certain meals.

\begin{tabular}{|l|l|l|l|l|l|l|l|}
\hline The & Always eaten & Rarely eaten & Absolute don't eaten & \\
\hline Category & No. & $\mathbf{\%}$ & No. & \% & No. & \% & Total \\
\hline The & & 52.63 & & 35.96 & & 11.40 & \\
\hline Students & 52 & & 36 & \multicolumn{2}{l|}{12} & & 100 \\
\hline Chi SQUARE
\end{tabular}

Table No. (4): The Kinds of snack food with the female student take it.

\begin{tabular}{|l|l|l|l|l|l|l|l|l|l|}
\hline $\begin{array}{l}\text { The } \\
\text { Category }\end{array}$ & $1^{*}$ & $2^{*}$ & $3^{*}$ & $4^{*}$ & $5^{*}$ & $6^{*}$ & $7^{*}$ & $8^{*}$ & Total \\
\hline $\begin{array}{l}\text { The } \\
\text { Students }\end{array}$ & 25 & 19 & 12 & 17 & 13 & 4 & 3 & 0 & 100 \\
\hline
\end{tabular}

1*- MacDonald's beef, 2*- MacDonald's Chicken, 3*- MacDonald's nuggets, $4 *$ - Pizza hut with cheese, $5 *$ - Pizza hot with vegetables, $6 *$ - Hardies Chicken, $7 *$ - Hardies beef, $8 *$ - Pizza dominos

Table No. (5):- The Relationship Between Body Mass Index Of Students With Their Fast Food Consumption.

\begin{tabular}{|l|c|c|c|}
\hline Body mass state & Always eaten & Rarely eaten & Total \\
\hline The thinness a thinner & $\mathbf{5}$ & $\mathbf{3}$ & $\mathbf{8}$ \\
\hline The healthy weight. & $\mathbf{2 9}$ & $\mathbf{5}$ & $\mathbf{3 4}$ \\
\hline Overweight & $\mathbf{3 2}$ & $\mathbf{6}$ & $\mathbf{3 8}$ \\
\hline The obesity & $\mathbf{1 2}$ & $\mathbf{0}$ & $\mathbf{1 2}$ \\
\hline \multicolumn{2}{|l}{} \\
\hline
\end{tabular}


Table No. (6):- The range of the student's intake of fast food from the foreign restaurants.

\begin{tabular}{|l|c|c|c|c|}
\hline consumption & $\begin{array}{l}\text { They take it two- } \\
\text { times a week. }\end{array}$ & $\begin{array}{l}\text { They take it three } \\
\text { times a week. }\end{array}$ & $\begin{array}{l}\text { They take it more than } \\
\text { three times a week. }\end{array}$ & The Total \\
\hline students & $\mathbf{4 0}$ & $\mathbf{3 2}$ & $\mathbf{2 8}$ & $\mathbf{1 0 0}$ \\
\hline Percent & $\mathbf{4 2 . 1 1}$ & $\mathbf{3 2 . 7 0}$ & $\mathbf{2 5 . 1 9}$ & \\
\hline Chi Square= (27.27) Confidence interval $-(0.01)$ & & \\
\hline
\end{tabular}

Table No. (7):- The relationship of the participants female students in the study and their bodies mass index with their fast food intake.

\begin{tabular}{|c|c|c|c|c|}
\hline $\begin{array}{l}\text { The body mass } \\
\text { state }\end{array}$ & $\begin{array}{l}\text { They take it two- } \\
\text { times a week. }\end{array}$ & $\begin{array}{l}\text { They take it three } \\
\text { times a week. }\end{array}$ & $\begin{array}{l}\text { They take it more than } \\
\text { three times a week. }\end{array}$ & The Total \\
\hline Thin & $\mathbf{3}$ & $\mathbf{3}$ & $\mathbf{2}$ & \\
\hline Normal Weight & $\mathbf{1 4}$ & $\mathbf{1 6}$ & $\mathbf{1 0}$ & \\
\hline Overweight & $\mathbf{1 8}$ & $\mathbf{1 1}$ & $\mathbf{1 0}$ & \\
\hline Obese & $\mathbf{3}$ & $\mathbf{2}$ & $\mathbf{7}$ & \\
\hline The total & $\mathbf{4 0}$ & $\mathbf{3 2}$ & $\mathbf{2 8}$ & \\
\hline Chi Square $=(13.01)$ & Confidence interval $=(0.1620$ & & \\
\end{tabular}

Table No. (8):- Students intake of the dinner meal that includes the light food contents.

\begin{tabular}{|c|c|c|c|c|c|}
\hline \multirow[t]{2}{*}{$\begin{array}{c}\text { The } \\
\text { Category }\end{array}$} & \multicolumn{2}{|c|}{$\begin{array}{l}\text { always take the dinner that includes Light } \\
\text { Contents. }\end{array}$} & \multicolumn{2}{|c|}{$\begin{array}{l}\text { It sometimes will be light in its } \\
\text { contents. }\end{array}$} & \multirow{2}{*}{$\begin{array}{c}\text { The } \\
\text { Tota } \\
\text { l }\end{array}$} \\
\hline & No. & $\%$ & No. & $\%$ & \\
\hline $\begin{array}{l}\text { The } \\
\text { Students }\end{array}$ & 6 & 7.02 & 94 & 84.2 & 100 \\
\hline
\end{tabular}

Table no. (9):-Effect of fast food consumption on blood glucose levels

\begin{tabular}{|c|c|c|c|}
\hline Statistical data & Group1 & Group2 & $\begin{array}{c}\text { Group2* } \\
\mathbf{1 . 4 1 \%}\end{array}$ \\
\hline Mean (mmol/l) & 4.61 & 4.73 & $* 6.08 \pm 2.02$ \\
\hline Std. Error of Mean & 0.06 & 0.05 & 0.16 \\
\hline Median & 4.40 & 4.61 & 4.90 \\
\hline Mode & 4.2 & 4.3 & 4.9 \\
\hline Std. Deviation & 0.48 & 0.63 & 0.87 \\
\hline Skewness & 1.88 & 1.93 & 0.41 \\
\hline Std. Error of Skewness & 0.25 & 3.8 & 6.0 \\
\hline Minimum & 3.7 & 6.8 & 7.2 \\
\hline Maximum & 6.2 & 3.94 & 4.00 \\
\hline Percentiles range & $2.5^{\text {th }}$ & 5.73 & 7.01 \\
\cline { 2 - 4 } & $97.5^{\text {th }}$ & & Mann-Whitney $<0.05$ \\
\hline
\end{tabular}

Group 1:- consumed two times a week

Group 2:- consumed three times a week or more

Table no. (10):- Lipid values for classification of hyperlipidaemias

\begin{tabular}{|c|c|c|c|}
\hline & Desirable & Borderline High Risk & High Risk CHD \\
\hline $\begin{array}{c}\text { Cholesterol: }(\mathbf{m g} / \mathbf{d l}) \\
\text { (mmol/l) }\end{array}$ & $<200$ & $200-239$ & $>240$ \\
\hline Triglycerides: $(\mathbf{m g} / \mathbf{d l})$ & $(5.18)$ & $(5.18-6.19)$ & $>500$ \\
(mmol/l) & $<250$ & $250-500$ & $(5.65)$ \\
\hline
\end{tabular}


Table no. (11):- Effect of fast food consumption on blood cholesterol levels

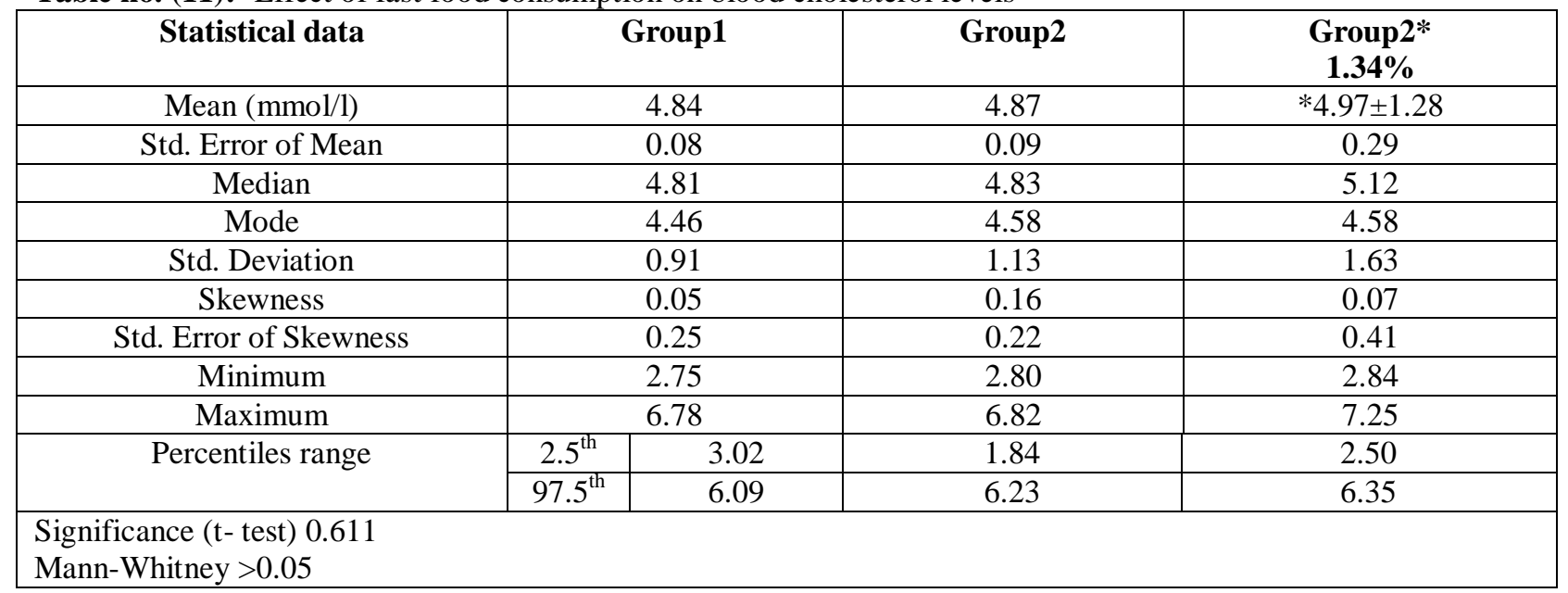

Group 1:- consumed two times a week

Group 2:- consumed three times a week or more

Table no. (12):- Effect of fast food consumption on blood triglycerides levels

\begin{tabular}{|c|c|c|c|c|}
\hline \multicolumn{2}{|c|}{ Statistical data } & Group1 & Group 2 & $\begin{array}{c}\text { Group 2* } \\
1.51 \%\end{array}$ \\
\hline \multicolumn{2}{|c|}{ Mean (mmol/l) } & 1.10 & 1.14 & $* 1.49 \pm 1.34$ \\
\hline \multicolumn{2}{|c|}{ Std. Error of Mean } & 0.04 & 0.05 & 0.09 \\
\hline \multicolumn{2}{|l|}{ Median } & 0.97 & 1.05 & 1.34 \\
\hline \multicolumn{2}{|l|}{ Mode } & 0.61 & 0.61 & 1.03 \\
\hline \multicolumn{2}{|c|}{ Std. Deviation } & 0.43 & 0.50 & 0.52 \\
\hline \multicolumn{2}{|l|}{ Skewness } & 1.27 & 1.07 & 0.75 \\
\hline \multicolumn{2}{|c|}{ Std. Error of Skewness } & 0.25 & 0.22 & 0.41 \\
\hline \multicolumn{2}{|l|}{ Minimum } & 0.37 & 0.38 & 0.82 \\
\hline \multicolumn{2}{|l|}{ Maximum } & 2.47 & 2.64 & 3.13 \\
\hline \multirow[t]{2}{*}{ Percentiles range } & $2.5^{\text {th }}$ & 0.39 & 0.44 & 0.82 \\
\hline & $97.5^{\text {th }}$ & 2.34 & 2.46 & 2.67 \\
\hline
\end{tabular}

Group 1:- consumed two times a week

Group 2:- consumed three times a week or more

\section{References:-}

1. Alfawaz, H. A.( 2012): The Relationship between fast food consumption and BMI among University Female Students. Pakistan J. Nutr., 11(5),406-410.

2. Al-Hazzaa H. M., Y. Al-Nakeeb, M. J. Duncan, H. I. Al-Sobayel, N. A. Abahussain, A. O. Musaiger, M. , Collins, P. and Nevill, A.. (2013): A Cross-Cultural Comparison of Health Behaviors between Saudi and British Adolescents Living in Urban Areas: Gender by Country Analyses. Int. J. Environ. Res. Public Health. 10(12), 6701-6720.

3. Al-Rethaiaa, A. S., Fahmy,A. A. and Al-Shwaiyat, N. M. (2010): Obesity and eating habits among college students in Saudi Arabia: a cross sectional study. Nutr. J. 9(39). doi: 10.1186/1475-2891-9-39.

4. Alviola IV, P. A., Nayaga Jr, R. , Danforth, M. D. and Smartt, J. (2014): The effect of fast restaurants on childhood obesity: A school level analysis. Economic and human biology.12, 110-119.

5. Anderson, B., Lyon-Cello, S., Imes, G. and Rafferty, A. P.(2011): Peer Reviewed: Consumption and obesity among Michigan adults. Preventing chronic disease.8(4).

6. Ashakiran Deepthi, R. 2012. Fast foods and their impact on health. Journal of Krishna Institute of Medical Sciences University. 1,7-15. 
7. Benajiba, N. (2016): Fast food intake among Saudi population: Alarming fact. Am. J. Food. Nutr. 6(2), 44-48. doi:10.5251/ajfn.2016.6.2.44.48.

8. Blume, L., Brock, W., Durlauf, S. and Jayaraman, R (2013): liner social interaction models, National Bureau of Economic Research, Working papers. w291221.

9. Cheristakis, N. and Flower, J. H. (2013): Social contagion theory: examining dynamic social networks and human behavior. Statistic in Medicine. 32(4), 556-557.

10. Clevidence, B. A., Reichman, M. E., Judd, J. T., Muesing, R., Schatzkin, A., Schaefer, E. J., Zhengling, L.,Jenner, J., Brown, C., Sunkin, M., Campbell W., and Taylor P.(1995): Effects of alcohol consumption on lipoproteins of premenopausal women. A controlled diet study. Atherioscler. Thromb. Vasc. Biol., 15, 179184.

11. Currie, J., DellaVigna, S., Moretti, E., and Pathania, V. (2010): The effect of food restaurants on obesity and weight gain. American Economic Journal: Economic Policy. 2, 32-63.

12. Francis, L. A., Lee, Y. and Birch, L. L. (2003): Parental weight status and girls' television viewing, snacking, and body mass indexes. Obesity Research. 11(1), 143-151.

13. Gold smith- Pinkham, P. and Imbens, G. W. (2013): Social networks and the identification of peer effects. Journal of business and Economic statistic. 31(3), 253-264.

14. Hegsted, D. M., Ausman, L. M., Johnson, J. A. and Dallal, G. E. (1993): Dietary fat and serum lipids: an evaluation of experimental data. American Journal of Clinical Nutrition. 57, 875-883.

15. Khamis, N., Mahnashi, M., Al-Dhaheri, A., Al-Zahrani, B., Al-Wadie, E., Aljabri, M., Al-Shanketi, R., Al-Shehri, R., Al-Sayes F. M. and Bashawri, J. (2014): Risk factors of coronary heart disease among medical students in King Abdulaziz University, Jeddah, Saudi Arabia. B.M.C. Public Health. 4(411). doi: 10.1186/1471-2458-14-411.

16. Ludwig, D. S. and E.Robert, H. (2002): The Glycemic index at 20 y. Am. J. Clin. Nutr. 76(1), 264S-265.

17. Maggio, C. and Pi-Sunyer, F. (2003): Obesity and type 2diabetes. Endocrinology and metabolism clinics of North America. 32, 805-822.

18. Merriam-Webster's. Online Dictionary. (2015): available at http://www.merriamwebster.com/dictionary/fast\%20food.

19. Monheit, A. C., Vistnes, J. P., and Rogowski, J. A. (2007): Overweight in adolescent: Implications for health expenditures. NBER, No. 13488. (Working Paper)

20. Musaiger, A. O., Lloyd, O. L., Al-Neyadi, S. M. and Bener, A. B.( 2003): Lifestyle factors associated with obesity among male university students in the United Arab Emirates. Nutr. Food Sci., 33(4), 145-147.

21. Musaiger, A. O. (1994): Nutritional Status and Dietary Habits of Adolescent Girls in Oman. Ecol. Food Nutr. 31: 227-237.

22. Musaiger, A. O. (2000): Bibliography on Obesity in the Arab Gulf countries. Bahrain Medical Bulletin, 22( 3), 142-147.

23. Musaiger, A. O. and Radwan, H. M., (1995): Social and Dietary Factors Associated with Obesity in University Female Students in UAE. J. Roy. Soc. Health, 115, 96-99.

24. Must, A., Spadano, J., Coakley, E. H., Field, A. E., Colditz, G., Dietz. W. H. (1999): The disease burden associated with overweight and obesity. Journal of the American Medical Association, 282 (16), 1523-1529.

25. Paeratakul, S., Ferdinand, D. P., Champagne, C. M., Ryan D. H. and Bray, G. A. (2003): Fast food consumption among U.S adult and children: Dietary and nutrient intake profile. J. Am. Diet. Assoc., 103(10), 1332-1338.

26. Phillips, M., Cataneo, R. N., Cheema, T. and Greenberg, J. (2004): Increased breath bio-markers of oxidative stress in diabetes mellitus. Clin Chim Acta., 344, 89-194.

27. Printice, A. M. and Jebb, S. A. ( 2003): Fast foods, energy density and obesity: a possible mechanistic link. Obesity Rev., 4, 187-94.

28. Rashad, I., MICHEAL, G. and Shin- Yi., C. (2006): The Super-size of America: An Economic Estimation of body Mass Index and Obesity in Adults. Eastern Economic journal, 32, 133-48.

29. Report of the National Cholesterol Education Program Expert Panel on Detection, Evaluation, and Treatment of High Blood Cholesterol in Adults. The Expert Panel. 1988. Arch. Intern. Med. Jan., 148(1), 36-69.

30. Roefs, A. and Jansen, A. (2002): Implicit and explicit attitudes toward high fat food in obesity. Journal of Abnormal Psychology, 111(3), 517-21.

31. Sabra, A. A., Taha, A. Z., Al-Sebiany, A. M., Al-Kurashi, N. Y. and Al-Zubier, A. G.(2007): Coronary heart disease risk factors: prevalence and behavior among male university students in Dammam City, Saudi Arabia. J Egypt Public Health Assoc., 82(1-2), 21-42. 
32. Sandra, P. D., Beate, L., Maike, j., Dominique, L. and Manfred, J. M. (2010): Determinants of the prevalence and incidence of overweight in children and adolescents. N. S. Public Health Nutrition, 4 Feb.1-12. doi:10.1017/S1368980010000583.

33. Schlosser, E. ( 2012): "Fast Food Nation”, First Mariner Book edition, pp 111-133.

34. Schmidt, M., Affenito, S. G., Striegel-Moore, R., Khoury, P. R., Barton, B., Crawford, P., Kronsberg, S.,Schreiber, G., Obarzanek, E. and Daniels, S. (2005): Fast-food intake and diet quality in black and white girls: The National Heart, Lung, and Blood Institute Growth and Health study. Arch. Pediatr. Adolesc. Med., $159,626-631$.

35. STAMPFER, M., Mason, J., Rimm, E., Colditz, G., Rosner, B. and Hu, F.(1997): Dietary fat intake and risk of coronary hat diseases in woman. New England journal of medicine, 337(21), 1491-9.

36. Tsung, O. C. (2009): FUND FOR NON-FAST FOOD. Int J Cardiol., Nov. 23, 145(1), 40.

37. WHO. (2016): Obesity and overweight. Report of a WHO Study Group, Geneva, World Health Org., Available from: http://www.who.int/gho/ncd/risk_factors/ overweight_text/en/. (Last accessed on 2015 Jul 13).

38. Yahia, N., Achkar, A., Abdallah, A., Rizk, S. (2008): Eating habits and obesity among Lebanese university students. Nutr. J., 7,32. 